\title{
The COVID-19 pandemic Resilience of Indonesian journalists
}

\begin{abstract}
The COVID-19 pandemic has forced the global news industry to adapt to the current crisis. In some Global South countries, challenges have also come from an existing political instability and economic limitations. Indonesia represents a Global South country where its journalists have struggled to maintain the quality of news while many have faced layoffs. This research involved a survey data with 100 respondents, some interviews and observations, which indicated that in the COVID-19 pandemic Indonesian journalists have been severely affected and are not sufficiently equipped or prepared to face any accelerated and sudden changes caused by the coronavirus. However, in some instances, journalists have been able to deploy advanced digital technology and work collaboratively to provide quality information during the pandemic. The article argues that mastering journalism data and collaborative work should be embraced to enhance the resilience of the journalist community.
\end{abstract}

Keyword: collaboration, COVID-19, data, Global South, health journalism, Indonesia, pandemic, resilience, surveys

\section{GILANG DESTI PARAHITA \\ Universitas Gadja Mada, Yogyakata}

OURNALISTS are important players in communicating information about health risks to the public, especially in public health emergencies. In such crises, the need for information is so urgent that the demands and expectations placed on journalists increase. However, it is not certain that journalists and media organisations are ready in Indonesia to face a public health emergency. News about health crises is often criticised because it perceived as sensational, incomplete, and inaccurate, leading to misunderstanding, panic or even public neglect. Although several studies have explored how well the media can work to provide quality information during a crisis (McCauley, Minsky \& Viswanath, 2013; Ma, 2005), there is limited research showing the resilience of the press in times of global health crises such as the COVID-19 pandemic.

In a global crisis, the media are no longer merely a stage for the global crisis, but rather become one of the actors on that stage (Cottle, 2009). The COVID-19 pandemic has broadly brought an impact on the economic, social and political sectors, including the media industry. A study of journalism resilience during the COVID-19 pandemic is deemed important considering that COVID-19 has 
become a new disruption to journalism and the Indonesian and global press industry. Lewis (2020) states that there is a need to reorient research agendas to be continuously responsive and reflective to cope with current crises and prepare for any future uncertainties.

In Indonesia, journalism is at a challenging stage to be observed in terms of its resilience in dealing with the COVID-19 pandemic. Indonesia has the fourth largest population in the world with 270.6 million. It is also one of the countries with the most serious impact from the COVID-19 pandemic with more than 4.09 million cases of infection and 133,000 deaths (Covid-19 Dashboard, 31 August 2021). When this article was being written, the number of Indonesia's COVID-19 cases peaked in June-July 2021 with the country's second wave and has since peaked again with the positivity rate during the second week of August reaching 19.25 percent (Covid19.go.id, 2021a). From the perspective of Indonesian public policy, economic consideration has strongly driven the government's strategy in tackling the COVID-19 pandemic (Apriliyanti, Utomo, Purwanto, 2021) as COVID-19 would reduce Indonesia's economic growth to between 1 and 4 percent (Suryahadi, Izzati, Suryadarma, 2020). Moreover, in the early phases of COVID-19, Indonesian government officials made several communication mistakes leading to public confusion (Mawardi, 2020).

The Indonesian media industry is greatly affected by the COVID-19 pandemic. Many print media have discontinued their operations caused by digitisation and worsened by the virus (Supadiyanto, 2020). The year before the COVID-19 pandemic swept the country in 2020, the government blacked out the internet in Papua for seven days during August 2019 in response to the offline and online protest movement \#PapuanLivesMatter (Juniarto, 2019). ${ }^{1}$ A number of articles in the Work Creation/Omnibus Law Bill, which were drafted by the government since the beginning of President Joko Widodo's second administration, have the potential to hinder press freedom.

Long before the COVID-19 pandemic, the press and media industry was concentrated on a group of media tycoons and formed an oligarchy (Tapsell, 2015). As part of the countries of the Global South, Indonesia has different characteristics from Northern countries in terms of social history, culture, politics, economy and the tendency of journalism practice and journalism education (Estella, 2020). In 1998, the toppling of Suharto regime marked the beginning of transitional democracy which is characterised by the reorganisation of political economic power from Jakarta (Mietzner, 2010). On the other hand, freedom of speech and the press is merely practised as liberalising the media industry, especially those privately owned in urban-based areas (Lim, 2012), and strengthening the 'freedom' of political interest of media owners rather than serving the public interest (Tapsell, 2015; Armando, 2014).While press freedom understanding is limited to freedom to conduct media business for the oligarchy the notion of protection 
of journalists' safety and rights has low priority (Parahita \& Ahmad, 2019).

In a situation where the press and media industry strengthens the political oligarchy, press freedom is interpreted in various ways. The COVID-19 pandemic poses a number of challenges for the Indonesian press, from understanding the first signs of the health crisis caused by COVID-19, and demanding the openness of the government. Also, it is for the press to remain independent, ensure accuracy and balance, care for vulnerable groups, as well as protect for journalists (Parahita, 2020). This article examines to what extent the resilience of the Indonesian press is able to face these challenges.

\section{The importance of journalism in times of a public health crisis}

In an uncertain and emergency situation such as an infectious disease outbreak, journalists are required to keep working to deliver information needed by the public. The guidelines for risk communication at the time of the outbreak issued by the World Health Organisations (WHO) (2009) stated that the purpose of communication before and during an outbreak is to provide and exchange relevant information to the public, partners and stakeholders. Ideally, decisions that are based on quality information can strengthen efforts to protect public health and safety. Specifically, the main objective of journalists in a public health crisis situation is to help to optimise public health goals while reducing public panic (Parmer et al., 2016; Lubens, 2015; Reynolds \& Quinn, 2008; Robie \& Krisnamurthi, 2020, Wilkins, 2005). The function of crisis journalism works well and when the press produces qualified news (Dudo et al., 2007).

Crisis journalism might encounter a number of obstacles. Inhibiting factors include the journalists' educational background, limited knowledge of journalists regarding the infectious disease outbreaks, time constraints, obstacles in finding sources, economic pressures, lack of training in the news organisations concerned, and journalists fast turnover with constant deadlines (Lowrey et al., 2006). Lubens (2015) stated that significant barriers to improve the quality of medical and health coverage include a lack of journalistic technical training, limited news production time, and commercial demands that drive the selection of stories and headlines.

In the COVID-19 pandemic, observing the journalism resilience is significant because the crisis has had a structural impact on the national and global press industry. The pandemic reinforces the idea of the importance of changing the financial structure of the media industry from relying on revenue from advertisers to opening up other revenue stream opportunities such as reader fees, donations, including government subsidies (Olsen, Pickard \& Westlund, 2020). With the increasing uncertainty due to COVID-19, several concerns related to journalism include the role of experts, the strength of the nation state, and the challenges in covering everyday changes (Kunelius, 2020). 
Resilience is the ability of an individual or organisation to adapt to a shocking event, or danger without being completely overtaken by the disaster. Resilience, according to (Vogus \& Sutcliffe, 2007), results from the processes and dynamics that maintain the cognitive, emotional, relational and structural resources that enable organisations to successfully cope with and learn from any unexpected events. At the individual level, the characteristics of resilience include the ability to improvise, adopt different roles, be able to effectively gather knowledge, and interact with others in a sensible manner. At the community level, resilience is built through processes of resistance, recovery and creativity (Weick, 1993).

\section{Science and disaster cognition}

With infectious disease outbreaks, journalism is expected to be able to build public awareness about the risks of a public health problem. The role of journalists and media organisations in disaster situations such as public health crises is often unattainable due to a lack of specialist journalist training, limited news production time, and the commercial demands requiring the selection of news and headlines (Lubens, 2015). Ideally, the press during a public health crisis needs to provide information related to prevent the spread of disease outbreaks (Dudo et al., 2007).

\section{Personal safety}

The COVID-19 pandemic has put journalists and media organisations in a threatened position as experienced by other members of society. Therefore, both journalists and media organisations in the current pandemic need to strengthen their physical and spiritual protection. The experience of protecting journalists from similar crises in the past has shown the neglect of the organisation on this side. Journalists in Australia interviewed by Hooker, King and Leask (2012) did not know the pandemic planning that had been carried out by their own organisation. The safety of journalists while on duty is the responsibility not only of individual journalists but also organisations, resource people, the state and society in general. In Indonesia, the issue of safety for journalists still becomes a concern due to the weak structural support (Parahita \& Ahmad, 2019). Lowrey et. al. (2006) emphasised the importance of individual journalist and organisational level readiness in maintaining the safety and security of journalists before, during and after coverage of infectious disease outbreaks.

\section{Mental health}

Apart from physical protection, the challenge of maintaining mental health during the COVID-19 pandemic is strengthening. Working from home (WFH), on one hand, protects journalists from the threat of COVID-19; on the other hand, they are also prone to mental disorders (Bernadas \& Ilagan, 2020) as a result of isolation and social distancing, the burden of household work, and mental violence from closest people. 


\section{Professionalism and innovative culture}

Technology development and open government are associated with increased surveillance of infectious diseases at the global level. Press freedom and widespread internet use in one country has accelerated the spread of public reports about outbreaks from one country to another. In practice, the local media might not necessarily convey infectious disease outbreaks in other countries to local audiences for various reasons.

The first challenge for journalists in public health and science issues today is how to quickly describe the risk of the outbreak. Unfortunately, in the context of COVID-19, journalists and global press media are late in giving early warnings about a possible pandemic due to censorship from the Chinese government, negligence by the government and the global press, as well as the passive resonance from WHO (Fu \& Zhu, 2020).

In times of public health crisis, journalists are pressured to confirm that the information is accurate along with demands for rapid information updates (Lubens, 2015). In addition, with an epidemic journalists face a dilemma when reflecting on their response to the deadly influenza outbreak. On the one hand, they must be informants who are independent and neutral to the public, and they are also expected to support public interests and support public health care workers (Hooker, King \& Leask, 2012).

The press during a public health crisis needs the government as a source of information in times of emergency but simultaneously monitors and criticizes them. Cornia et al. (2016) stated that the professional culture of journalists in each country's context would shape the journalist-government relationship and the construction of the pandemic reality in a specific way. In the Netherlands, a survey of journalists showed that journalists act as watchdogs in crisis news but they tend to use familiar sources (van der Meer et al., 2017).

Another challenge is that journalists must balance the need to address the humanist aspects of their stories and to protect the patients' dignity while simultaneously describing the severity of an epidemic within a very limited time frame (Lubens, 2015). They are unlikely to explain the complexity (Leask, Hooker \& King, 2012; Ward, 2019).

The degree of innovative culture within the editorial room is being tested during the crisis (García-Avilés, 2021). At the very least, Cornia et al. (2016) examined three ways that the 2009 bird flu pandemic was covered in Europepartisan, watchdog and technocratic. The current COVID-19 pandemic also forces journalists to further hone their skills in digitally producing journalistic reports and competing against disinformation (Luengo \& Garcia-Marin, 2020; Tejedor et al., 2020; Perreault \& Perreault, 2021, Robie \& Krishnamurthi, 2020). 


\section{Relational aspect}

The COVID-19 pandemic has the worst impact among economically marginal groups and other vulnerable groups such as medical personnel and paramedics, people with disabilities, the elderly, pregnant women and children, people with certain illnesses, migrants and refugees who do not speak local languages. In July 2006, 24 individuals from 11 countries met in Bellagio, Italy to discuss current responses and potential responses to an influenza pandemic, which was likely to have a major effect on marginalised groups and to recommend a number of steps to prevent or at least mitigate this effect (Uscher-Pines et al., 2007).

\section{Diversity in economic resources and audience participation}

With the slowing economic growth due to COVID-19, the media industry is experiencing an economic crisis. Dawson et al. (2020) noted that while the need for journalists in the press industry in Australia is increasing, the skills required by a journalist have also increased despite getting a disproportionate return on income. The situation has been evolving since 2012 and COVID-19 is only exacerbating the situation. The journalism funding crisis experienced globally prompted Olsen, Pickard and Westlund (2020) to initiate the urgency of communal journalism work and its financing.

\section{Research method}

To examine how resilient Indonesian journalists are to the COVID-19 pandemic, an online survey using Survey Monkey was carried out on journalists in Indonesia. Respondents obtained the links through the Alliance of Independent Journalists (AJI), an association of reformist journalists in Indonesia. The survey link was distributed for two weeks between 28 August-12 September 2020. A total of 117 journalists gave a response, but only 100 responses were filled in completely and considered in the findings. The questions were answered with Yes, No, and Unsure. The analysis was carried out with a frequency distribution. Table 1 shows the respondent profiles:

Research was also carried out by closely observing announcements and news releases from the Indonesian Journalists Alliance Indonesia (AJI), and interviewing a number of journalists, such as the chief of employment division of AJI Indonesia Endah Lismartini and chief of programme division AJI D.I. Yogyakarta, Bhekti Suryani. Observations were also made on an online discussion between Communication Science of Gadjah Mada University students and the editorial chief of Narasi TV, Zen Rahmat Sugito, AJI's press release documents uploaded at aji. or .id, and government policies that have an impact on the press /media industry in Indonesia. 


\section{Table 1: Respondents' profile in percentage $(\mathrm{N}=100)$}

\begin{tabular}{|c|c|}
\hline \multicolumn{2}{|l|}{ A. Gender } \\
\hline Male & 80 \\
\hline Female & 20 \\
\hline \multicolumn{2}{|l|}{ B. Media Organisation } \\
\hline Print & 40 \\
\hline TV/Radio & 5 \\
\hline Online & 25 \\
\hline Convergent & 30 \\
\hline \multicolumn{2}{|l|}{ C. Career Period } \\
\hline Less than 5 years & 20 \\
\hline $5-10$ years & 30 \\
\hline $10-20$ years & 40 \\
\hline More than 20 years & 10 \\
\hline \multicolumn{2}{|l|}{ D. Beat } \\
\hline Urban & 35 \\
\hline Politics & 18 \\
\hline Economy and Business & 16 \\
\hline Education & 7 \\
\hline Social and Culture & 17 \\
\hline International & 1 \\
\hline Entertainment and Lifestyle & 5 \\
\hline \multicolumn{2}{|l|}{ E. Location of Media Offices } \\
\hline DKI Jakarta & 33 \\
\hline West Java & 15 \\
\hline Yogyakarta Special Province and Central Java & 23 \\
\hline East Java & 4 \\
\hline Sumatra Island & 15 \\
\hline Kalimantan Island & 7 \\
\hline Sulawesi Island & 3 \\
\hline
\end{tabular}

\section{Results and discussion}

\section{Media industry resilience at the expense of the journalists}

Journalism has a number of roles in public health crisis situations. However, in severe disaster situations such as the COVID-19 pandemic, journalists and media 
organisations need to find ways to survive and recover enabling them to continue to function to serve the public. In the midst of the COVID-19 pandemic, media workers remained hopeful to present the latest and quality information to the public, both from a government official statement and complemented from field coverage, academic studies and sources. As early as in March 2020, some Indonesian news outlets produced \#medialawancovid (\#mediaagainstcovid) to raise COVID-19 concern, awareness and anticipation towards the virus among citizens (Ekarina, 2020).

Indonesia news is to provide a guidance to the community to survive in this incredible plague. At the same time, journalists are a social group prone to be infected with COVID-19. Being observed from the website of AJI Indonesia (www.aji.or.id), during March-July 2020 AJI Indonesia often released alerts to media companies and official institutions to improve their efforts in protecting journalists' health from the COVID-19 threat and be transparent in implementing COVID-19 protocols (Febrina, 2020).

COVID-19 affects all sectors in society including the politics and economy. As seen from Table 2 , the respondents seemed to agree that the pandemic dominantly impacts almost all areas being asked including increasingly restricting regulation, mental difficulties, personal safety unpreparedness, changing working pattern, employment crisis, and disinformation spread. COVID-19 has become an apology for the Indonesian government to impose some regulations that weaken the press freedom.

There are two regulations in which AJI Indonesia sees them as a form of repression against press freedom:

1. The Supreme Court issued Supreme Court Regulation (Perma) Number 52020 on Trial Protocols and Security in the Court Environment as stipulated on 27 November 2020. One of the regulations stipulated is that any photographing, audio recording and audio-visual recording must have the permission of the judge or chairman of a panel of judges. This provision is contained in Article 4 paragraph 6, which reads, 'Taking photos, audio recordings and/or audio-visual recordings must have the permission of the judge/chair of the Panel of Judges before the commencement of the trial". The violation of Article 4 paragraph 6 qualifies as an insult to the court.

2. The Chief of the State Police Regulation of the Republic of Indonesia issued an edict Number: Mak /1/I/2021 concerning Compliance with the Prohibition of Activities, Use of Symbols and Attributes and the Termination of Activities of the Islamic Defenders Front (FPI), signed on 1 January 2021. From an AJI Indonesia perspective, the announcement of the chief of police in Article $2 \mathrm{~d}$ seems to be excessive and inconsistent with the spirit as a democratic country that respects the right of the people to obtain and disseminate information. 


\begin{tabular}{|c|c|c|c|c|}
\hline \multicolumn{5}{|c|}{ Table 2: Impacts of COVID-19 on Indonesian journalists ( $N=100)$} \\
\hline Types of Impact & Statements & $\begin{array}{l}\text { Yes } \\
\%\end{array}$ & $\begin{array}{c}\text { No } \\
\%\end{array}$ & $\begin{array}{c}\text { Unsure } \\
\%\end{array}$ \\
\hline \multirow{5}{*}{$\begin{array}{l}\text { 1. Weak freedom } \\
\text { of the press and } \\
\text { personal safety }\end{array}$} & Increasing the restricting regulation & 71 & 4 & 25 \\
\hline & Experiencing more physical threats & 16 & 21 & 63 \\
\hline & Experiencing more verbal threats & 19 & 33 & 42 \\
\hline & Experiencing more digital threats & 21 & 42 & 37 \\
\hline & $\begin{array}{l}\text { Increasing the awareness of per- } \\
\text { sonal safety unpreparedness }\end{array}$ & 76 & 3 & 21 \\
\hline \multirow{2}{*}{$\begin{array}{l}\text { 2. Threats to phy- } \\
\text { sical and mental } \\
\text { health }\end{array}$} & Being exposed to COVID-19 & 0 & 91 & 9 \\
\hline & $\begin{array}{l}\text { Enduring mental challenges like } \\
\text { stress/depression }\end{array}$ & 47 & 19 & 34 \\
\hline \multirow{4}{*}{$\begin{array}{l}\text { 3. Changing work- } \\
\text { ing pattern }\end{array}$} & $\begin{array}{l}\text { Increasing challenges to verify } \\
\text { information }\end{array}$ & 26 & 63 & 11 \\
\hline & $\begin{array}{l}\text { Using advanced technology more } \\
\text { intensively }\end{array}$ & 73 & 17 & 10 \\
\hline & Using more official sources & 54 & 25 & 21 \\
\hline & Applying safety protocol & 64 & 10 & 26 \\
\hline \multirow{4}{*}{$\begin{array}{l}\text { 4. Employment } \\
\text { crisis }\end{array}$} & Salary deduction & 90 & 10 & 0 \\
\hline & Paid employment break & 5 & 95 & 0 \\
\hline & Work termination & 2 & 98 & 0 \\
\hline & Early retirement & 3 & 97 & 0 \\
\hline $\begin{array}{l}\text { 5. Increasing disin- } \\
\text { formation spread }\end{array}$ & $\begin{array}{l}\text { Increasing disinformation from } \\
\text { social media }\end{array}$ & 100 & 0 & 0 \\
\hline
\end{tabular}

Although most of the respondents felt that they did not experience any increasing physical and digital threats during work, it did not mean the violence did not occur. The Alliance of Independent Journalists (AJI) Indonesia recorded that some journalists experienced digital threats like doxing (Ni'matun, 2020a). 2020 was also marked by the ratification of the Omnibus Law on the Work Creation Act, as issued by the government and the DPR on 5 October 2020. The law was considered to provide privilege for investors and was detrimental to many parties, including workers. AJI Indonesia recorded that journalists have become the victims of police violence while covering rallies, which have contributed greatly to the increase in the number of cases of violence against journalists in 2020 (Manan, 2020). Magdelene.co and Konde.co, two media outlets that routinely voice the rights of women and minority groups, have also come under digital attack (Manan, 2020). 
Working remotely also faces its own challenges; the respondents admitted that they found it difficult to verify information during the pandemic. This situation has been recorded by AJI Indonesia as well. Laziness to verify information becomes a problem when the news is proven to be inaccurate. It emerged when some mass media journalists quoted news from Indonesia's news agency ANTARA, while the news quoted was actually inaccurate-even verging on being a hoax (Ni'matun, 2020b).

The conglomeration and concentration of the Indonesian media industry might enable the industry to be resilient during the pandemic as it can subsidise the platform weakened by the COVID-19 pandemic and could rationalise the number of workers. On the other hand, it does a disservice to journalists. The employment status of the respondents is severely hit by the pandemic. A great number of the respondents admitted that their salary had been cut. The coordinator of Employment Division AJI Indonesia, Endah Lismarini, recorded that many well-established media in Indonesia had made an adjustment related to financial aspects during the crisis by cutting or delaying the salaries or wages, terminating contracts, and offering early retirement to the journalists although the companies had received incentives from the government (personal communication, May 24, 2021).

On July 2020, the Indonesian government announced that it would provide seven incentives for the media industry - abolishing value added tax (VAT) for newsprint, postponing electricity payments, suspending health and employment insurance payments, exempting income tax, and diverting advertising budgets to local media industries (Arigi, 2020). The Fellowship for Behavior Change, which was initiated by the Covid-19 Task Force and the Press Council, was also run from October-December 2020 and will be continued by May-December 2021. The Fellowship involves 26 senior journalists as editors and more than 3030 journalists from various regions. Through his media release, the chairman of the Press Council, Mohammad Nuh, exclaimed that the participants would receive a monthly remuneration allocated from the APBN (National Budget) but they are expected to remain critical in reporting the issues of health protocols and behavior change.

A Press Council commissioner, Agus Sudibyo, on a webinar, 'Relaxing Journalism in the Mid-Pandemic Covid-19', on Saturday, 10 July 2021, gave assurances that the government would not intervene in the editorial process of any news produced by fellow journalists in the programme. The programme is a middle way to support quality journalism, which is rocking financially and to let journalists oversee and remain critical of any governmental mitigation programmes.

While the policies are generally enjoyed by media companies, an improper contract termination has taken place in some firms. AJI Jakarta recorded that online media company Kumparan.com, which is not conglomerated with other companies, fired 
some of their journalists and blamed this on the pandemic (AJI Jakarta, 2020). Seeking the alternative of press funding other than advertising is not commonly practised in Indonesian press culture. Before the pandemic, sponsorship required the media to conduct offline events. However, COVID-19 pandemic has ended the trend. According to the coordinator of the employment division, AJI Indonesia, Endah Lismarini,

[n]ot many media workers have an urge to protest because the advertisers cut their budget to advertise in media. However, AJI Indonesia called on the media companies to be fair and involve their workers in decision making. (Lismarini, personal communication, 2021).

Professional and trade associations provide a stronger bargaining position for journalists to defend their rights. Employment adjustments are getting worse within media companies that do not have trade unions because journalists and other workers have little bargaining leverage (Lismarini, personal communication, 2021). Some of the companies with trade unions even do not discuss the problem and solution with the workers. Thus, the fate of journalists is decided one-sidedly by the management. Since November 2020, until this article was being written, AJI Indonesia has often conducted workshops supported with grants and fellowships to increase the capacity of the journalists in covering issues related to COVID-19, including how to fact-check disinfodemic as reported on its website (www.aji.or.id). With its international networks such as International Federation of Journalist (IFJ), Thomson Foundation, Maverick Indonesia, and Google News Initiative, associations like AJI Indonesia becomes increasingly strategic in crises such as the COVID-19 pandemic when people need to overcome the effect of the plague together.

The tendency of low resilience among Indonesian journalists was reflected from the survey data showing that Indonesian journalists seemed quite illprepared to deal with crises caused by COVID-19 in almost every area surveyed (Table 3).

The respondents admitted that they did not have similar experiences in science, environmental and public health issues. This might have been a phenomenon in the Indonesian media industry as not every news platform provides science/health beats (rounds); thus, not all journalists deserve to be called science/crisis journalists. Most of them are unsure and not well-trained in personal safety issues, although their daily work even put them at risk of violence before the pandemic. Interestingly, the percentage of mentally well-managed respondents dominated the responses although only half of them had received mental health support from their organisations. Table 3 also portrays the limited networks relevant with the pandemic for the journalists to adapt, including conducting collaborative projects, extending contact with science and medical communities, and reaching marginalised communities to be portrayed as the resilient communities. 


\section{Table 3: Resilience perceptions Indonesian journalists}

\begin{tabular}{|c|c|c|c|c|}
\hline $\begin{array}{l}\text { Resilience } \\
\text { Components }\end{array}$ & Statements & $\begin{array}{c}\text { Yes } \\
\%\end{array}$ & $\begin{array}{c}\text { No } \\
\%\end{array}$ & $\begin{array}{c}\text { Unsure } \\
\%\end{array}$ \\
\hline \multirow{2}{*}{$\begin{array}{l}\text { 1. Cognition about } \\
\text { disasters, risks, the } \\
\text { science communi- } \\
\text { ty and the science } \\
\text { culture }\end{array}$} & $\begin{array}{l}\text { Having attended the training on risk/ } \\
\text { disaster/science journalism }\end{array}$ & 25 & 50 & 25 \\
\hline & $\begin{array}{l}\text { Having knowledge about similar events in } \\
\text { the past (e.g. crisis, disaster, etc.) }\end{array}$ & 30 & 60 & 10 \\
\hline \multirow[b]{2}{*}{ 2. Personal safety } & $\begin{array}{l}\text { Attending journalist self-safety training } \\
\text { for infectious epidemics }\end{array}$ & 20 & 45 & 35 \\
\hline & $\begin{array}{l}\text { Getting personal safety equipment sup- } \\
\text { port for journalists from the } \\
\text { organisation }\end{array}$ & 50 & 30 & 20 \\
\hline \multirow[b]{2}{*}{ 3. Mental health } & $\begin{array}{l}\text { Maintaining mental health during a } \\
\text { pandemic }\end{array}$ & 80 & 4 & 16 \\
\hline & $\begin{array}{l}\text { Getting mental health disorder preven- } \\
\text { tion support for journalists from the } \\
\text { organisation }\end{array}$ & 40 & 40 & 20 \\
\hline \multirow{4}{*}{$\begin{array}{l}\text { 4. Professionalism } \\
\text { and innovation } \\
\text { culture }\end{array}$} & Applying the verification in reporting & 80 & 10 & 10 \\
\hline & $\begin{array}{l}\text { Balance information from multiple } \\
\text { sources }\end{array}$ & 70 & 20 & 10 \\
\hline & $\begin{array}{l}\text { Being able to conduct fact-checking to } \\
\text { fight disinformation/misinformation } \\
\text { related to COVID-19 }\end{array}$ & 60 & 30 & 10 \\
\hline & $\begin{array}{l}\text { Mastering new technologies/applica- } \\
\text { tions that help journalistic practice }\end{array}$ & 70 & 20 & 10 \\
\hline \multirow{3}{*}{$\begin{array}{l}\text { 5. Relational } \\
\text { aspect }\end{array}$} & $\begin{array}{l}\text { Conducting a collaborative work with } \\
\text { journalists from other media companies }\end{array}$ & 30 & 50 & 20 \\
\hline & $\begin{array}{l}\text { Extending a contact with the science } \\
\text { and medical communities for informa- } \\
\text { tion related to COVID-19 }\end{array}$ & 30 & 50 & 20 \\
\hline & $\begin{array}{l}\text { Reaching marginalised groups to be } \\
\text { portrayed as reliant citizens (e.g. senior } \\
\text { citizens, women, LGBT, workers, etc }\end{array}$ & 30 & 50 & 20 \\
\hline \multirow{3}{*}{$\begin{array}{l}\text { 6. Diversity in eco- } \\
\text { nomic resources } \\
\text { and audience } \\
\text { participation }\end{array}$} & $\begin{array}{l}\text { Media organisations guarantee journal- } \\
\text { ists' work contracts during the COVID-19 } \\
\text { pandemic }\end{array}$ & 40 & 40 & 20 \\
\hline & $\begin{array}{l}\text { Engaged in organisational efforts to in- } \\
\text { crease the diversity of sources of income } \\
\text { for the media }\end{array}$ & 10 & 80 & 10 \\
\hline & $\begin{array}{l}\text { Engaged in organisational efforts to } \\
\text { increase audience participation in the } \\
\text { editorial process }\end{array}$ & 10 & 80 & 10 \\
\hline
\end{tabular}

Note: Perceptions of Indonesian journalists in performing resilience during the COVID-19 pandemic. 
Even though the data generally captured the bleak ability of Indonesian journalists to survive in the pandemic, it is only in the professionalism and innovation culture aspect where most of the respondents felt obliged to comply. Their perception is that they have maintained ethical practices such as verification and balanced reporting, conducted fact-checking, and even adapted to new technologies allowing them to do online interviews. A report created by Narasi TV, 62 Menit Operasi Pembakaran Halte Sarinah (Narasi Newsroom (2020), 62 minutes of burning Sarinah bus stop operation) uploaded on YouTube performed an advanced digital analysis approach to news reporting. ${ }^{2}$ Narasi TV is an onlinebased media initiated by Nadjwa Shihab, a former reporter of Metro TV, a terrestrial Jakarta-based TV channel. The video was uploaded on 28 October 2020, or 20 days after the incident of the Sarinah fire. In an online class of Journalism of the Communication Science Department, Gadjah Mada University, on Friday, 27 November 2021, editorial chief of Narasi TV Zen Rahmat Sugito explained that open source intelligence/investigative (Osint) reporting was feasible because the editorial team had recorded some live and open source CCTV video at the riot and burning incident in Sarinah bus stop and analysed 250 of them. Narasi TV then concluded the arsonists were not a part of the protest. The conclusion rejected accusations that the protesters had conducted a violent rally.

Aside from the use of technology in covering news, collaborative reporting is also on the rise in Yogyakarta (population 423,000). In the Special Region of Yogyakarta, a city about 566 kilometres from the capital of Jakarta, some journalists have worked collaboratively to produce news. The programme coordinator of AJI Yogyakarta, Bhekti Suryani, reported that some news correspondents and local journalists had worked collaboratively to produce news. AJI Yogyakarta has coordinated news related to the topics of local believers and agrarian affairs in Yogyakarta, since late 2020. Both sets of coverage have been supported by external funding. SATUNAMA, a Yogyakarta-based NGO, funded the cost of covering local believers and disability issues which were published in late 2020 . The Open Society Foundation through Kurawal Foundation funded the cost of covering agrarian affairs in Yogyakarta, which was still ongoing when this article was being written (Suryani, personal communication, 2021). On agrarian affairs, 15 journalists from more than five news companies were involved.

Agrarian affairs in Yogyakarta is a sensitive issue. As a special region in Indonesia, Yogyakarta is privileged to manage its administration. It is the only province out of 34 in Indonesia that does not elect its governor and vice-governor. Both of the top positions in Yogyakarta are given to the family of its Yogyakarta Sultanate (Keraton Yogyakarta) and Pakualaman Sultanate (Pura Pakualam). However, the regents/mayors of five districts are elected in local elections. Law No. 132012 about Privilege (UU Keistimewaan Yogyakarta) allows the authority of Yogyakarta to regulate and administer the Sultan and Pakualaman Grounds. Nevertheless, the 
law causes problems with duality and conflicts over land ownership (Jati, 2014).

In the early period of the pandemic, Suryani, who works for Harian Jogja, collaborated with colleagues from Kompas, Gatra, VOA, Tirto, CNNIndonesia and IDNTimes to cover issues related to COVID-19 policies in Yogyakarta. The topic included comparing the number of COVID-19 cases data between official data and COVID-19 ward, investigating the official method of COVID-19 patients' classification, and criticising the reluctance of the government to apply a local lockdown.

In doing the collaboration, they divided small tasks among themselves, but they took part in the interview together. When the information and data were complete, they agreed on the news angle and narrative. They wrote the articles independently to prevent and avoid 'cloning' journalism. Their individual segments of the reports were published in each channel. For this work, Suryani (2021) testified that they were not funded by any institutions.

We believe that as journalists, we have to keep on being critical [towards] government and policies. Even though we receive external grants, we make sure that the funding institution does not control our process and results. Beyond that, experience, passion, integrity and idealism in quality journalism have motivated us to conduct a collaborative-investigative work. (Suryani, personal communication, 2021).

The journalists involved in collaborative COVID-19 reporting were inspired by their previous project covering corruption in the auction of disputed land of former cinema Indra in Yogyakarta a year earlier (Suryani, personal communication, 2021). During the pandemic, to cover corruption is more difficult because government officials are more remote, and 'emotional closeness' between local journalists with their sources and 'envelope culture' are not reduced. ${ }^{3}$ Suryani cited Indonesialeaks.id to provide an example of how collaborative reporting has been practised at the national level. Indonesialeaks.id is a platform created by journalists from various media that receive documents and information digitally and online. Its breaking news included the Buku Merah case in 2019 (Indonesialeaks, 2019). Another example is the collaborative reportage by The Jakarta Post, Vice Indonesia and Tirto.id on sexual harassment in Indonesian campuses during 2019 which drew national attention (Tirto.id).

\section{Conclusion}

The COVID-19 pandemic is not the first time Indonesian journalism has experienced a crisis. With the strengthening of the digitisation of information and the media, journalism continues to be forced to adapt. It can be stated that COVID-19 intensifies the pre-existing disruption of the routines of journalists so far. In an Indonesian context, journalists encounter challenges, including a lack of media freedom and personal safety, threats to physical and mental health, 
changing working patterns, employment crises, and an increasing disinformation spread. The capacity of Indonesian journalists to be resilient is seen in the aspects of ability to maintain mental health and consistently implement professional ethics. Some media companies were financially affected due to Covid-19 but the Indonesian government has imposed fellowship programmes to assist the media industry to keep producing quality COVID-19 journalism — and the government promises to allow independent and critical reports.

In regard to pandemic reporting, journalists who master advanced technology and have collaborative working relations with their peers - whether through associations or local and international networks - are likely to be able to produce quality news during the COVID-19 pandemic. Data and visual reportage, when done independently, cleverly and carefully attract large numbers of views and influences public opinion. Indonesian journalists who are able to collaborate with their peers and networks find that in-depth and investigative reporting remain feasible for production even during the crisis.

Data and collaborative reporting is something new in Indonesia. However, the COVID-19 pandemic seems to accelerate the idea in which immediate and exclusive news are no longer critical with the 'new normal' of journalism in Indonesia. Technologically advanced, collaborative and inclusive reporting increases the resilience of the Indonesian journalists in remaining critical and productive. In the end, those who benefit the most from public-interest and collaborative journalism is society as a whole.

As Indonesian journalists might tend to respond to questionnaires of professionalism from a sense of idealism, the best way to verify the statistical result is by content analysis of their published reports. Future research may include the quality of COVID-19 journalism produced by the journalists enrolling in government fellowship programmes, and the continuation of technologically advanced as well as collaborative reporting.

\section{Notes}

1. George Floyd's killing in the United States reverberated across Indonesia, triggering a groundswell of support for \#BlackLivesMatter and also for Papuans in a country that 'often avoids confronting national traumas'. George Perry Floyd Jr was an African-American man murdered by a white police officer in Minneapolis, Minnesota, who kneeled on his neck for more than nine minutes on 25 May 2020. Derek Chauvin was convicted on three counts of homicide and sentenced to 22.5 years in jail. Three other police officers face trial in 2022. The hashtag \#Papuanlivesmatter quickly attracted backing from actors, artists and many of Indonesia's progressive youth. University students organised online seminars with Papuans and human rights activists, 'sparking conversations that would have never happened in the past. And non-Papuans have taken to the streets calling for change, including in a city [Tasikmalaya] better known for its Islamic schools.' (Papuans are largely 
Christian, a religious minority in the predominantly Muslim country.) (Pierson, 2020).

2. Sarinah bus shelter here refers to Transjakarta bus stop situated nearby Sarinah Mall in the heart of Special Capital Region of Jakarta. At least two Transjakarta bus shelters in Central Jakarta are damaged and burned during the protest rally against the controversial Job Creation/Omnibus Law on October 8, 2020 (Facilities set ablaze, 2020).

3. Journalists receive money from the news sources when they attend sources' press conference/publish news. The money was put into envelopes (Romano, 2000)

\section{References}

AJI Jakarta. (2020). Berdalih efisiensi akibat pandemi, Kumparan, PHK Karyawan. Retrieved from https://ajijakarta.org/2020/07/10/\%EF\%BB\%BFberdalih-efisiensiakibat-pandemi-kumparan-phk-karyawan/

Apriliyanti, I.D., Utomo, W.P., \& Purwanto, E.P. (2021). Examining the policy narratives and the role of the media in policy responses to the COVID-19 crisis in Indonesia. Journal of Asian Public Policy, https://doi.org/10.1080/17516234.2021.1954770

Arigi, F. (2020). Insentif industri media dari pemerintah untuk hindari PHK. Retrieved from https://nasional.tempo.co/read/1369040/7-insentif-industri-media-dari-pemerintah-untuk-hindari-phk

Armando, A. (2014). The greedy giants: Centralized television in post-authoritarian Indonesia. The International Communication Gazette, 76(4-5), 390-406. doi: https:// doi.org/10.1177/1748048514524106

Bernadas, J.M.A.C., \& Ilagan, K. (2020). Journalism, public health and COVID-19: some preliminary insights from the Philippines. Media International Australia, 177(1), 132-138. https://doi.org/10.1177/1329878X20953854

Cornia, A., Ghersetti, M., Mancini \& Odén, T. (2016). The partisans, the technocrats and the watchdogs. Journalism Studies, 17(8), 1030-1050. https://doi.org/10.1080/ 1461670X.2015.1040891

Cottle, S. (2009). Global crises in the news: Staging new wars, disasters and climate change. International Journal of Communication, 3, 494-516. https://ijoc.org/index. php/ijoc/article/view/473/326

Covid-19 Dashboard (2021, August 31). Center for Systems Science and Engineering (CSSE) at Johns Hopkins University (JHU). Retrieved September 1, 2021, from https://www.arcgis.com/apps/dashboards/bda7594740fd40299423467b48e9ecf6

Covid.19.go.id. (2021a). Grafik kasus aktif, kasus sembuh dan kasus meninggal per provinsi (update per 27 Agustus 2021). Retrieved August 30, 2021, from https:// covid19.go.id/berita/grafik-kasus-aktif-kasus-sembuh-dan-kasus-meninggal-provinsiupdate-27-agustus-2021

Covid.19.go.id. (2021b). Pasien sembuh terus meningkat mencapai 3.571 .082 orang. Retrieved from https://covid19.go.id/berita/pasien-sembuh-terus-meningkat-mencapai-3571082-orang.

Dawson, N. et al. (2020). Layoffs, inequity and COVID-19: A longitudinal study of the journalism jobs crisis in Australia from 2012 to 2020. Journal Title, XX(X). Retrieved from https://arxiv.org/pdf/2008.12459.pdf

Dudo, A.D., Dahlstrom, M.F., Brossard, D. (2007). Reporting a potential pandemic: 
A risk-related assessment of avian influenza coverage in US newspapers. Science Communication, 28(4), 429-454. https://doi.org/10.1177/1075547007302211

Donsbach, W. (2014). Journalism as the new knowledge profession and consequences for journalism education. Journalism, 15(6), 661-677.

Ekarina, (2020). \#medialawancovid-19 usaha media dorong kesadaran publik akan korona. (\#medialawancovid-19 media efforts to encourage public awareness of corona.) Retrieved from https://katadata.co.id/ekarina/berita/5e9a4212a09d2/medialawancovid-19-usaha-media-dorong-kesadaran-publik-akan-corona.

Estella, P.G. (2020). Journalism competence and the COVID-19 crisis in Southeast Asia: Toward journalism as a transformative and interdisciplinary enterprise. Pacific Journalism Review, 26(1): 15-20. https://doi.org/10.24135/pjr.v26i2.1132

Facilities set ablaze as clashes breakout in Jakarta during jobs law protest (2020, October 8). The Jakarta Post. Retrieved from https://www.thejakartapost.com/ news/2020/10/08/facilities-set-ablaze-as-clashes-breakout-in-jakarta-during-jobslaw-protest.html

Febrina. (2020). Seruan AJI Indonesia: Publik butuh informasi terpercaya, hindari PHK atau penundaan gaji pekerja media. Retrieved from https://aji.or.id/read/pressrelease/1039/seruan-aji-indonesia-publik-butuh-informasi-terpercaya-hindari-phkatau-penundaan-gaji-pekerja-media.html

Fu, K.W., Zhu, Y. (2020). Did the world overlook the media's early warning of COVID-19? Journal of Risk Research, 1-5, https://doi.org/10.1080/13669877.2020.1756380.

García-Avilés, J.A. (2021). Review article: Journalism innovation research, a diverse and flourishing field (2000-2020). Profesional de la información, 30(1): e300110. Retrieved from http://www.profesionaldelainformacion.com/contenidos/2021/ene/garcia.html

Hodgetts, D., et.al. (2008). Constructing health news: possibilities for a civic-oriented journalism. Health, 12(1), 43-66.

Hooker, C., King, C., Leask, J. (2012). Journalists' views about reporting avian influenza and a potential pandemic: a qualitative study. Influenza and Other Respiratory Viruses, 6(3), 224-220. https://doi.org/10.1111/j.1750-2659.2011.00319.x

Indonesialeaks. (2019). Bukti baru buku merah. Retrieved from https://kbr.id/nasional/10-2019/indonesialeaks_bukti_baru_buku_merah/100941.html

Indonesian Press Council (May 11, 2021). Press council appreciates behavior change journalism fellowship [Media release]. Retrieved from https://dewanpers.or.id/assets/ documents/siaranpers/2021-05-11._Dewan_Pers_Apresiasi_Fellowship_Jurnalisme_Ubah_Laku-release_formal.pdf.

Jati, W.R. (2014). Politic of agrarian in Yogyakarta: Partimonial identity and law dualism. Jurnal Legislasi Indonesia, 11(1), 25-37.

Juniarto, D. (2019). Apa yang terjadi saat Internet di Papua dimatikan selama 7 hari. Retrieved from https://kumparan.com/damar-juniarto/apa-yang-terjadi-saat-internetdi-papua-dimatikan-selama-7-hari-1rkDFLZeJWv

Kunelius, R. (2020). On the overlap of systemic events: COVID-19, climate and journalism. Social Media + Society, 1-4. https://doi.org/10.1177/2056305120948197

Leask, J., Hooker, C., King, C. (2010). Media coverage of health issues and how to work more effectively with journalists: a qualitative study. BMC Public Health, 10(535). http://www.biomedcentral.com/1471-2458/10/535 
Lewis, S.C. (2020). The objects and objectives of journalism research during the coronavirus pandemic and beyond. Digital Journalism, 8(5), 681-689. https://doi.org/10 $.1080 / 21670811.2020 .1773292$

Lim, M. (2012). The league of thirteen media concentration in Indonesia. Arizona: Participatory Media Lab at Arizona University and Ford Foundation.

Lowrey, W., Gower, K., Evans, W., Mckay, J. (2006). Assessing newspaper preparedness for public health emergencies. Journalism and Mass Communication Quarterly, 83(2), 362-380. https://doi.org/10.1177/107769900608300209

Lubens, P. (2015). Journalists and public health professionals: Challenges of a symbiotic relationship. Disaster Medicine and Public Health Preparedness, 9(1), 59-63. doi:10.1017/dmp.2014.127

Luengo, M. \& Garcia-Marin, D. (2020). The performance of truth: politicians, factchecking journalism, and the struggle to tackle COVID19 misinformation. American Journal of Cultural Sociology, 8, 405-427. https://doi.org/10.1057/s41290-020-00115-w

Ma, R. (2005). Media, crisis ad SARS: An introduction. Asian Journal of Communication, 15(3), 241-246.

Manan, A. (2020). Catatan akhir tahun AJI 2020: Tahun kelam bagi Jurnalis Indonesia. AJI.or.id. Retrieved from https://aji.or.id/read/press-release/1142/catatan-akhir-tahunaji-2020-tahun-kelam-bagi-jurnalis-indonesia.html

Mawardi, I. (2020). Ini daftar pernyataan blunder pemerintah soal coroba versi LP3ES. Detik.com. Retrieved from https:/news.detik.com/berita/d-4967416/ini-daftar37-pernyataan-blunder-pemerintah-soal-corona-versi-lp3es

McCauley, M., Minsky, S. \& Viswanath, K. (2013). The H1N1 pandemic: media frames, stigmatization and coping. BMC Pubic Health, 13, 1116. https://doi.org/10.1186/14712458-13-1116

Mietzner, M. (2010). Indonesia's direct elections: Empowering the electorate or entrenching the new order oligarchy? In E. Aspinall \& G. Fealy (Eds.), Soeharto's new order and its legacy. Essays in honour of Harold Crouch, Canberra, ACT: Australian National University E-Press.

Narasi Newsroom (2020). Buka mata: 62 menit operasi pembakaran halte Sarinah. Retrieved from https://www.youtube.com/watch?v=Pfjjn0dk_iA

Ni'matun, N. (2020a). AJI kecam-intimidasi terhadap dua jurnalis cekfakta Tempo. AJI. or.id. Retrieved from https://aji.or.id/read/press-release/1092/aji-kecam-intimidasiterhadap-dua-jurnalis-cek-fakta-tempo.html

Ni'matun, N. (2020b). AJI kecam pemberitaan tak akurat soal pernyataan Nicholas Youwe. AJI.or.id. Retrieved from https://aji.or.id/read/press-release/1218/aji-kecampemberitaan-tak-akurat-soal-pernyataan-opm-nicholas-youwe-berpotensi-hoaks.html

Olsen, R. K. Pickard, V., \& Westlund, O. (2020). Communal news work: COVID-19 calls for collective funding of journalism. Digital Journalism, 8(5), 673-680. https:// doi.org/10.1080/21670811.2020.1763186

Parahita, G.D. (2020). Lima Dimensi Jurnalisme Krisis Covid-19. Mas’udi, W. \& Winanti, P.S. (eds.) Tata Kelola Penanganan COVID-19 di Indonesia: Kajian Awal. UGM Press: Yogyakarta.

Parahita, G.D., \& Ahmad, N. (2019). What dampen the Indonesian's journalist freedom and safeness in the post-Soeharto new order?' In S. Jamil (Ed.), Handbook of research on combating threats to media freedom and journalist safety. IGI Global.

Parmer, J., Baur, C., Eroglu, D., Lubell, K., Prue, C., Reynolds, B., \& Weaver, J. (2016). Crisis and emergency risk messaging in mass media news stories: Is the public getting the information they need to protect their health? Health Communication, 31(10),1215- 
1222. https://doi.org/10.1080/10410236.2015.1049728

Indonesian Press Council (May 11, 2021). Press council appreciates behavior change journalism fellowship [Media release]. Retrieved from https://dewanpers.or.id/assets/ documents/siaranpers/2021-05-11._Dewan_Pers_Apresiasi_Fellowship_Jurnalisme_Ubah_Laku-release_formal.pdf.

Perreault, M. F. \& Perreault, G.P. (2021). Journalists on COVID-19 journalism: Communication ecology of pandemic reporting. American Behavioral Scientist, 1-16.

Pierson, D. (2020, July 2). George Floyd's death inspires an unlikely movement in Indonesia: Papuan lives matter, Los Angeles Times. Retrieved September 1, 2021, from https:/www.latimes.com/world-nation/story/2020-07-02/papuan-lives-matter

Reynolds, B., \& Quinn, S.C. (2008). Effective communication during an influenza pandemic: The value of using a crisis and emergency risk communication framework. Health Promotion Practice, 9(4), 13S-17S. https://doi.org/10.1177/1524839908325267

Robie, D., \& Krishnamurthi, S. (2020). FRONTLINE: The sociology of a pandemic: Countering a COVID 'disinfodemic' with a campus media initiative. Pacific Journalism Review : Te Koakoa, 26(2), 179-200. https://doi.org/10.24135/pjr.v26i2.1131

Romano A. (2000). Bribes, gifts and graft in Indonesian journalism. Media International Australia. 94(1),157-171. https://doi.org/10.1177/1329878X0009400115

Supadiyanto. (2020). (Opportunities) death of newspaper industry in digital age and COVID-19 pandemic. The Messenger Journal, 12(2), 192-207. https://doi.org/10.26623/ themessenger.v12i2.2244

Suryahadi, A., Izzati, R.A., \& Suryadarma, D. (2020). SMERU working paper: the impact of COVID-19 outbreak on poverty: an estimation for Indonesia. Jakarta, Indonesia: The SMERU Research Institute.

Tapsell, R. (2015). Indonesia's media oligarchy and the 'Jokowi phenomenon'. Indonesia, 99, 29-50. https://doi.org/10.5728/indonesia.99.0029

Tejedor, S. et.al. (2020). Information on the COVID-19 pandemic in daily newspapers' front pages: Case study of Spain and Italy. International Journal of Environmental Research and Public Health, 17. https://doi.org/10.3390/ijerph17176330

Tirto.id. (2019). Nama baik kampus. Retrieved from https://tirto.id/kekerasan-seksualdi-kampus-djiR.

Uscher-Pines, L., Duggan, P.S., Garoon, J.P., Karron, R.A. \& Faden, R.R. (2007). Planning for an influenza pandemic: social justice and disadvantaged groups. Hastings Center Report, 37(4), 32-39. https://www.jstor.org/stable/4625761

van der Meer, T. G. L. A. et al. (2017). Disrupting gatekeeping practices: Journalists' source selection in times of crisis. Journalism, 18(9), 1107-1124. https://doi. org/10.1177/1464884916648095

Vogus, T.J. \& Sutcliff, K.M. (2007). Organizational resilience: Towards a theory and research agenda. Proceeding IEEE International Conference on Systems, Man, and Cybernetics, 3418-3422. https://doi.org/10.1109/ICSMC.2007.4414160.

Ward, J.K. (2019). Boundary-making in the media coverage of the 2009 pandemic flu vaccine's safety in France. Sociologie 10/4. Retrieved from https://journals.openedition.org/sociologie/6070\#tocfrom 1n1.

Weick, K. E. (1993). The collapse of sense making in organizations: The Mann Gulch disaster. Administrative Science Quarterly, 38(4 ), 628-652.

Wilkins, L. (2005). Plagues, pestilence and pathogens: The ethical implications of news reporting of a world health crisis. Asian Journal of Communication, 15(3), 247254. https://doi.org/10.1080/01292980500260698

World Health Organisation, (2009). Pandemic influenza preparedness and response: 
A WHO guidance document. Retrieved from https://apps.who.int/iris/bitstream/han dle/10665/44123/9789241547680_eng.pdf?sequence=1.

\section{Personal communication}

Endah Lismartini, chief of the employment division of AJI Indonesia, Yogyakarta, 24 May 2021.

Bhekti Suryani, chief of programme division AJI D.I., Yogyakarta, 25 May 2021.

\section{Regulation}

Law No. 13 year 2012 about Privilege (UU Keistimewaan Yogyakarta)

Gilang Desti Parahita is an assistant professor in the Department of Communication Science, Faculty of Social and Political Sciences, Universitas Gadjah Mada (UGM), Jogyakarta, Indonesia. Her research topics include digital journalism, new media and marginalised communities and communication for sustainable development.

gilang_parahita@ugm.ac.id

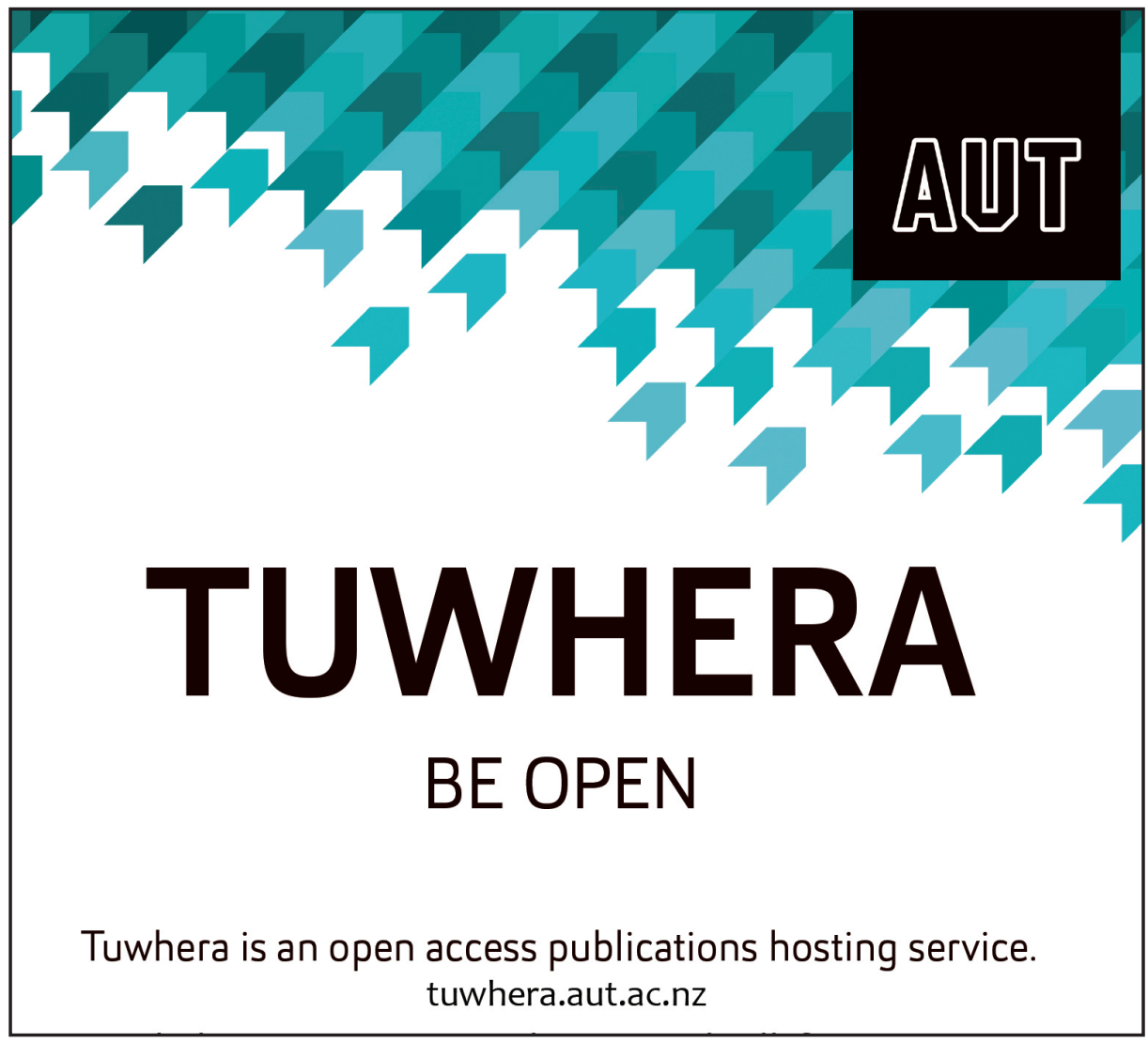

